\title{
Istanbul as Palimpsest: The Black Book as a Postmodernist Representation of Turkish History and Culture
}

\author{
Aneesa Ayanee \\ Assistant Professor \\ Deptt. of English \\ Govt. College for Women \\ Nawakadal, Srinagar, Jammu and Kashmir, India \\ aneesa.ayanee@gmail.com
}

But what is suppressed comes back. And it has come back in a new way. Somehow, in literature, I am myself that thing that comes back, but I came back with my postmodern forms.

Orhan Pamuk

Abstract

Orhan Pamuk's novel, The Black Book is a postmodern chronicle of Turkey in which the author uses the structure of a detective novel to delineate the themes of identity, culture and hybridity. The paper aims to depict how Pamuk foregrounds that identities are never determinate but are forever eluding by presenting a love triangle which disappears underneath a mystical quest for one's true self. Galip's assuming the persona of his alter-ego, Celal; Prince Osman's pursuit of true knowledge through reading diverse books and ultimately rejecting them; and Bedii Usta's disillusion with the State for disapproving the mannequins, all represent the interlacing of cultures and interdependence of identities in contemporary Turkey. Moreover, in the novel, the rich Ottoman tradition and Islamic literature are also revisited in a postmodern light so as to present the allegorical and political connotations inherent in them. The paper also examines how the novel portrays the forced westernization 
and erasure of history and memories through the use of film ekphrasis to highlight how the Turkish citizens were lured by the Western cinema and indoctrinated about the superiority of the West so as to generate in them a sense of anxiety about their identities.

Keywords: Turkey, Culture, Identity, Mannequins, Westernization, Film Ekphrasis.

The Black Book is a detective novel set in Istanbul before the military coup of 1980 happened. Although the novel revolves around three characters-Galip, Celal and Ruya, the city of Istanbul emerges as a central character. Galip, a lawyer in his early thirties comes home one evening to find that his wife, Ruya (her name means "dream" in Turkish), who also happens to be his first cousin, has left him without any explanation. He makes a frantic search through the apartment but is unable to find any clue and, therefore, decides to look for her. He telephones her friends and acquaintances in vain and speculates that she has gone back to her ex-husband, tracks him down but is disappointed to find that she is not with him. On finding that Celal, Ruya's half-brother and the famous newspaper columnist, is also missing, Galip (who has been fanboying Celal for a long time) determines that the two are hiding in one of Celal's secret apartments. Inferring that understanding Celal's mind and thoughts may lead him to a possible clue about his whereabouts, Galip breaks into his attic apartment, pores over his columns, wears his clothes and inadvertently starts living his idol's life. Galip, who is shown discontented with his life and yearning for an alternative life, has always desired to be like his cousin, Celal. However, his hunt for Celal leads him to the exploration of his own self and he is able to come to terms with his identity even as he resigns to the fact of meaninglessness of life.

Interspersed within the frame narrative are Celal's covertly political columns for Milliyet, a Turkish newspaper, which are eventually written by Galip after his disappearance. As Galip attempts to recollect the past and deconstruct present, themes of memory, history, identity and originality come up which are then exhaustively debated by Celal in the 
philosophical columns alternating with Galip's narration. Celal takes the classics from the rich eastern literature and influences his readers to look at them in a new way justifying his postmodernist stance by claiming that even great writers like Rumi have copied ideas from others: "... the important thing was not to create something, but to draw instead from the marvels created over thousands of years by the many thousands of great minds who'd come before us, to change here and there and turn it into something new ..." (The Black Book 259). In an interview for The Paris Review, Orhan Pamuk talks about the influence of the immensely rich American culture on his writing technique which prompted him to write modern national literature that rendered traditional source into an innovative style quite different from the writing practice adopted by the socially committed writers of the century. Pamuk remarks that the reactionary and political connotations of Islamic literature were subdued by the conservative writers to an extent that their redemption seemed impossible. He believes that the same literature can be approached with a "Calvinoesque" or a "Borgesian" attitude so as to appropriate its literary connotations, allegories and gimmicks into a highly innovative content. Pamuk sees such possibilities in the oral narrative traditions of China, Persia and India and uses this experimental style in his Black Book which comes out as a Dadaist collage. He says: “... The Black Book has this quality. Sometimes all these sources are fused together and something new emerges. So I set all these rewritten stories in Istanbul, added a detective plot, and out came The Black Book" (Other Colours: Essays and a Story $367)$.

In The Black Book, Pamuk parodies the abortive westernization carried out by the Republican government by showing that the Turks lost their essence after they were forced to adopt modernity. This is best exemplified in the novel in the accounts of the mannequin maker, Bedii Usta, which he narrates to Celal. He notifies the columnist about the reason of his working underground saying that the religious bodies opposed his lifelike mannequins 
and termed his art sinful when he started his career. After the westernization of the nation he became hopeful that his mannequins shall be displayed in the clothing stores but they were rejected as they were modelled on Turks and not Europeans which the countrymen were aspiring to be. A shopkeeper explained to Bedii Usta: “... Turks no longer wanted to be Turks, they wanted to be something else. This was why they'd gone along with the "dress revolution", shaved their beards, reformed their language and their alphabet" (The Black Book 61). He was told by other storekeeper that it is not the dress that allures the customer but the "dream of becoming "the other" who'd worn that dress" (The Black Book 61). However, this did not stop Bedi Usta to pursue his dream and he persevered secretly in his art explaining that he will preserve in his dummies the gestures which he believes is the essence of Turks and unlike other things like history and culture, gestures cannot be changed. After some time he observed some changes in the gestures of people who were losing their novelty gradually and imitating western films. He laments: "They were discarding their old ways, faster than the eye could see; they'd embraced a whole set of gestures-each and every thing they did was an imitation" (The Black Book 63). At first he captured these new and fake gestures in his art but then he became upset with the "hybrids" the Turks were turning into and retired to his atelier claiming to have understood the essence of the mystery. On seeing the mannequins, Celal identifies with them and discerns what that essence was. Celal compares them with the "deities mourning their lost innocence ... longing but failing to be someone else" who had in past known some essence but forgotten it. "It was this lost memory that pained us, reduced us to ruins, though still we struggled to be ourselves", writes Pamuk (The Black Book 64). Galip too chances upon the underground mannequins, now in possession of Bedii Usta's grandson who acts as his guide and tells him about his family's struggle. He tells Galip that it was his grandfather who started working underground to thwart the international conspiracy which encouraged Turks to change themselves and the legacy 
was continued by his father who on discovering a number of underground passages decided that Istanbul was "an underground city" and their history can only survive underground elucidating that "each incarnation of this city-Byzantium, Vizant, Nova RomaConstantinople, Cospoli, Istin-Polin - had beneath it the underground passages in which the previous civilization has taken refuge" (The Black Book 189) and in the resultant "double city", the hidden city below the ground avenges the over ground city ultimately.

Orhan Pamuk makes use of "film ekphrasis", according to Ece Aykol, to highlight the historical situation in Turkey and the novel is loaded with passages alluding to the political atrocities as can be seen in the discussion about films and monuments. Yesilcam (Turkish film industry) melodramas intimated in The Black Book are the localized adaptations of the American films in which the two groups - the westward looking elites and the anti-western commoners - were seen in opposition. The lifestyle of the families depicted in these movies was shown to be the exemplar for Turks, the implication being that the society could become progressive only by adopting the western way of life. However, different classes reacted to these movies differently. The conservatives found the characters and their values alien and viewed these films as a propagandist tool employed by the rulers to corrupt people. And the elites approved of these movies and imitated the western lifestyle shown in them. In the novel, Ruya's ex-husband complains about the westernization process that forced Turks to sever their ties with the past and observes that the movie method proved most effective for wiping out the memories of people. Allured by these films, he argues, the common people tried and failed to adopt their lifestyles and became miserable and those who identified with them became accomplices of the masters. Believing Istanbul to be the breeding-ground of evil, he pities Galip for belonging to the place pervaded with decay and believes that revival can only begin in shantytowns where the essence is still preserved. Ece Aykol, in her essay, "The Black Book: Ekphrastic Landscape", calls these films escapist and utopian because in 
these films the urban elites and the rural 'others' were shown reaching an understanding while as the two groups continue to remain irreconcilable in contemporary Turkey. Moreover, these films, Aykol adds, form an important part of collective memory for capturing "imperial" Istanbul now altered and transformed by history and hence find important place in Pamuk's novel as a mnemonic device.

Pamuk deconstructs the hegemonic narratives and uniform histories to highlight multiple perspectives, different experience and attitudes as well as many truths to present past in a new light. Rita Sakr examines the representation of monuments in Pamuk's novels as a political critique against the "violence of monumentalisation" and unidimensional representation. Quoting Henri Lefebvre according to whom monuments have multiple meanings and serve a specific purpose, she infers that monuments have the propensity to erase violence and terror present in social practices and replace them with tranquillity and certitude. Sakr highlights how the delineation of Ataturk's statues in The Black Book reveal the "violence and terror" buried under the general image of "tranquil power and certitude" associated with them and offers the reader to revisit the "discursive violence and violent histories that mark the texture of monumental space and the act of monumentalisation" (229). In The Black Book, Celal's reader-cum-stalker talks with Galip, whom he mistakes for Celal, about one of his columns regarding an apocalyptic event in which the statues of Ataturk will come alive. Envisaging the apocalypse, Celal paints the picture of ten thousand statues, some donning European clothes stained with pigeon droppings and the others wearing military outfits coming to life and trampling on the flowers and wreaths before disappearing in night. Celal conjures up the view of wretched citizens shuddering indoors as they hear the sounds of destruction besides "the rumble of bronze boots and marble hooves in the street outside" (The Black Book 357). According to Sakr, Pamuk not only satirises the monument making frenzy in Republican Turkey encouraged by Ataturk himself to set up the "Ataturk cult" but also 
desacralizes the image of Ataturk by mentioning the pigeon droppings on the statues which rips off the superhuman attributes usually associated with monuments and emphasizes the commonplace. Besides the attire worn by the statues serves to critique various elements of the Kemalistic policy while the western dress put on by the statue is a jibe at dress reform and the reference to the military attire is a disapprobation of military coups. Moreover, the wretched citizens, Sakr observes, convey the message of submissiveness and surrender of people to the recurring military intervention and the flowers and wreaths deride the passive commemorative "rituals of cultic devotion". She Writes:

By means of the apocalyptic trope ... Pamuk's narrative effects a blasting of one-sided historical accounts thus substituting multiplicity for a linear and univocal reading of Ataturk's legacy and its refractions in twentieth-century Turkey. While the apocalyptic trope often functions in the discourses of politicians as a technique of rhetorical violence and ideological manipulation couched in quasi-religious terms, here it performs the complex and paradoxical role of emphasising and parodying the violence of a history where stasis and repetition masquerade deceptively as dynamic moments: incomplete revolutions, repressive coups, commemorative monotony, and social paralysis.

Furthermore, while Galip is staying at Celal's place he gets a phone call from a man who mistaking him for Celal tells him that he admires his writings and desires to meet him. The man claims that he is in possession of some secrets of national importance which he wishes to reveal to Celal and insists for his address. The man confesses that he has so long believed Celal to be a messiah and spent a great deal of his life reading and re-reading his columns trusting them to contain some great secrets. But he no longer admires Celal as he is able to see through his betrayal and is furious at him for misleading his readers for years. And 
the real reason for his wish to arrange a meet with Celal is to get answers from him as he is convinced that all his writings alluding to the essence and redemption had been an illusion. Fittingly, Pamuk speaks of the influence enjoyed by Turkish columnists whom he labels "Professors of Everything" and says that they were as famous as "the most powerful politicians" and enjoyed the "reader's trust and affection" (Other Colours 293).

The Black Book is Pamuk's postmodern representation of Turkish history and culture where the eastern and western practices have merged to create a hybrid identity inhabiting diverse elements. However, in the Turkish society, different groups imposing different reforms have resulted in dilemmatic individuals forever in search of their true selves. Galip's story of the Prince Osman Celalettin Efendi's quest for authentic identity pertinently emphasizes the identity crisis experienced by Turks. Whereas the narrative about mannequins serves as a critique of westernisation, the tale of the Crown Prince underlines the implications of cultural isolation as well as complete dependence on the past. The Crown Prince initially believes that reading will help him with ideas that could be used to restore the glory of Ottoman Empire and he prepares himself for the future reign by reading voraciously and moves to the small hunting lodge far from the ignorant world. But then he realises that harbouring the ideas of others means to be impersonating "the other" and the important thing in life was to find a way to be oneself and it is only by finding this secret people can be saved from slavery and defeat because "all peoples who are unable to be themselves, all civilizations that imitate other civilizations ... were doomed to be crushed, destroyed, and forgotten" (The Black Book 429). So he discards all books and attempts to forget everything he had learnt from them. Further, to stop getting influenced by anything, the Prince cuts off the relations with people and lives in complete isolation. However, the Prince fails in his mission and dies envying the stones and rocks of the places undiscovered and uninfluenced by anybody. Through this story Pamuk seems to show the impossibility of achieving a pure 
identity which he has often discussed in other works and consequently critics have often used the bridge metaphor while analysing his work. It is neither achievable to regain the lost Ottoman past completely as shown in the fatal endeavour of the Prince, nor is it probable to embrace the west entirely as revealed by the melancholic citizens. Pamuk, therefore, endorses an in-between position in which the Turks will benefit from both Eastern and Western cultures.

Conclusion

The Black Book interweaves the Eastern and Western literary traditions to present Ottoman history and cultural identity in a postmodern narrative that defies monolithic accounts in favour of plurality. The book is representative of the author's disregard of cultural and historical violence done by both the nationalistic as well as external agencies and explicates how a vibrant Turkish culture can survive by striking a balance between various influences. Talking about the ill-conceived westernization process, Pamuk observes that the ruling elite failed to construct "a national culture" having "its own symbols and rituals". He laments that the local Istanbul culture, having Eastern and Western elements in combination which would have resulted into the creation of new and original culture rather than an imitation, was not formed: "They did not strive to create an Istanbul culture that would be an organic combination of East and West ...” (Other Colours 369). He hopes that future generations will be able to form a new culture for their nation since copying the west blindly or going back to the non-extant Ottoman culture is not a solution. 


\section{Works Cited}

Aykol, Ece. "The Black Book: Ekphrastic Landscape". Essays Interpreting the Writings of Novelist Orhan Pamuk. Ed. Nilgun Anadolu-Okur. University of Michigan: Edwin Mellen Press, 2009. PDF.

Pamuk, Orhan. Other Colours: Essays and a Story (Maureen Freely, Trans.). London: Faber and Faber, 2011.

---. The Black Book. London: Faber and Faber, 2006.

Sakr, Rita. "Between Terror and Taboo: Monumentalisation as the Matrix of History and Politics in Orhan Pamuk's The Black Book and Snow". British Journal of Middle Eastern Studies. 38.2 (Aug. 2011): 227-247. Web. 